\title{
OPTIMIZATION OF HIGH-PRECISION CYLINDER MANUFACTURING
}

\author{
Peter Eniko, Davorin Kramar
}

Original scientific paper

This paper deals with the reaming process optimization. The aim of optimization is that with controlled process suitable geometrical specifications could be achieved without final honing. To attain systematic improvements in manufacturing technology, transparent approach with the use of quality tools has been selected. SPC of bore cylindricity and surface roughness $(R a)$ of the original reaming process shows poor process capability and demonstrates shortcomings of the clamping device. Feed rate and spindle speed were identified as key factors in achieving required bore tolerances. Plan of experiments and process modelling was performed by DOE methodology. Regression analysis gives models for both responses, and they are adequate at $73 \%$ and $96 \%$ confidence level respectively. Optimization model was implemented in real production.

Keywords: cylinder bore; Design of Experiments (DOE); honing; reaming; Statistical Process Control (SPC)

\section{Optimizacija proizvodnje visokopreciznog cilindra}

Izvorni znanstveni članak

Rad se bavi optimizacijom postupka razvrtanja provrta tako da se kontroliranim postupkom mogu postići odgovarajuće geometrijske specifikacije bez završnog honanja. U svrhu sistematskog poboljšanja proizvodne tehnologije, izabran je transparentni postupak uz primjenu kvalitetnih alata. SKP cilindričnosti provrta i hrapavosti površine $(R a)$ originalnog postupka razvrtanja pokazuje slabu mogućnost obrade i ukazuje na nedostatke uređaja za stezanje. Brzina posmaka i brzina vretena prepoznati su kao ključni čimbenici u postizanju odgovarajućih tolerancija provrta. Plan eksperimenata i modeliranje postupka određeni su DOE metodologijom. Regresijskom analizom dobiveni su modeli za oba tražena odgovora (cilindričnost provrta i hrapavost površine) sa $73 \%$ i $96 \%$ pouzdanosti. Model optimizacije primijenjen je u stvarnoj proizvodnji.

Ključne riječi: honanje; plan eksperimenata (DOE); provrt cilindra; razvrtanje; Statistička kontrola postupka (SKP)

\section{Introduction}

Small batch production is due to the competitiveness of the market mainly orientated in achieving the required specifications with minimal manufacturing processes using standard cutting tools [1]. Costume made hydraulic valves are one of unique cases of small batch production in combination with high tolerances requirements [2]. Honing represents the final manufacturing process, which enables achieving geometric requirements for valve's cylinder bore and requires pre-processing on $\mathrm{CNC}$ machining centre with successive cutting processesdrilling, milling and reaming. Pre-processing on CNC machining centre is required because work piece should be machined in one clamping only in order to reach technological specifications. Specifications of the cylinder bore of the hydraulic valve housing prescribe cylindricity $/ 0 / \leq 12 \mu \mathrm{m}$ and surface roughness $R a \leq 1,6 \mu \mathrm{m}$ after reaming and cylindricity $/ \circ / \leq 3 \mu \mathrm{m}$ and surface roughness $R a \leq 0,4 \mu \mathrm{m}$ after honing.

This paper deals with the optimization of the reaming process on CNC centre. Process monitoring and optimization was performed by Statistical Process Control (SPC) and Design of Experiments (DOE) methodology [3]. Measuring method for bore cylindricity was defined as suggested in studies of De Chiffre et al. [4], Goeldel et al. [5], Stepien [6], and Wen et al. [7] and surface topology with mean roughness parameter $R a$ as in Brito et al. study [8].

Factors that have been identified as key factors to achieve specifications are bold highlighted in cause-andeffect diagram (Fig. 1), and have been studied within the experimental work. Authors as De Chiffre et al. [4], Korkut et al. [9], Müller et al. [10] and Xiao et al. [11] investigated spindle speed Sandfeed rate $f$ as numeric control factors within the reaming process studies. In this study feed rate and spindle speed of the reaming process, were selected as key control factors as well. Region of operability was defined, for both control factors, during pre-experiments.

Burlikowska [12] and Hassan et al. [13] are focused on pattern recognition in SPC charts in their studies. Jose et al. [14], Goldarag et al. [15] and Tadic et al. [16] present weaknesses and strengths of clamping devices on the $\mathrm{CNC}$ machining centres in achieving the desired results of experimental work and further production.

With complementariness of conclusions from mentioned studies and pre-experiments results, lack of clamping device rigidity was defined and minimized with focusing on only one (of three) clamping nests.

Impacts of the drill bit and the milling cutter tool life, the material of the cutting tool, the work piece material, cutting tool holder, the geometry of the work piece, and the characteristics of lubricant were neglected during research.

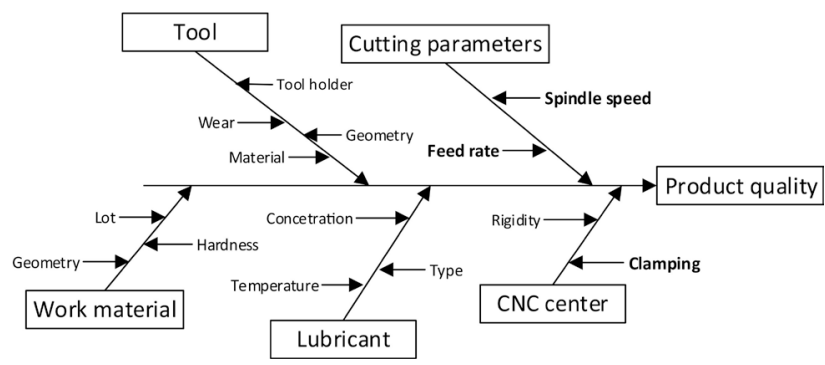

Figure 1 Cause-and-effect diagram for reaming process

They were neglected because the experiments were carried out on the same type of product, i.e. material and batch were the same and the same cutting tool was used. Drilling and milling parameters settings were not changed during experimental work. 
Resulted multi-criteria optimization enables achieving of required specifications of cylinder bore by $\mathrm{CNC}$ machining and improves reaming process capability, which results in drastic honing time reduction.

\section{Approach and method}

In order to achieve improvements in manufacturing technology a systematic approach with the use of SPC as in Burlikowska [12] and DOE as in Montgomery [17] has been selected. The original production technology provides a reference level to assess the improvements that have been achieved with a DOE strategy with the objective of fulfilling specifications in a cost-effective manner.

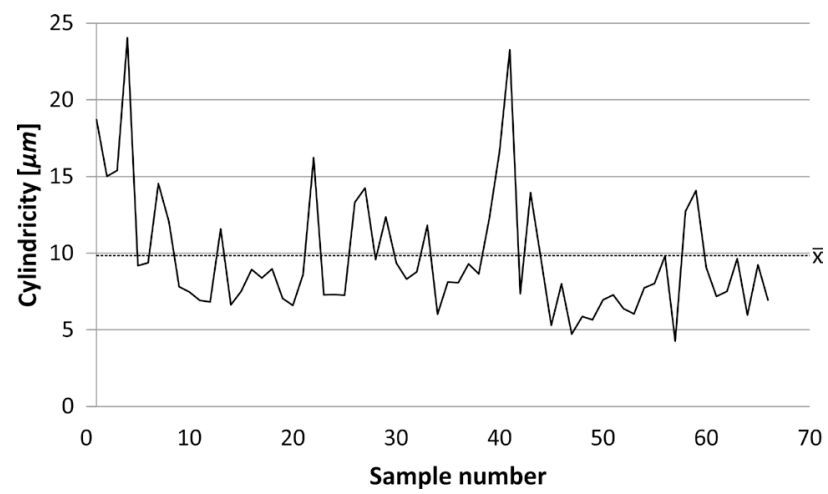

Figure 2 Cylindricity x-control chart; monitoring of original reaming process

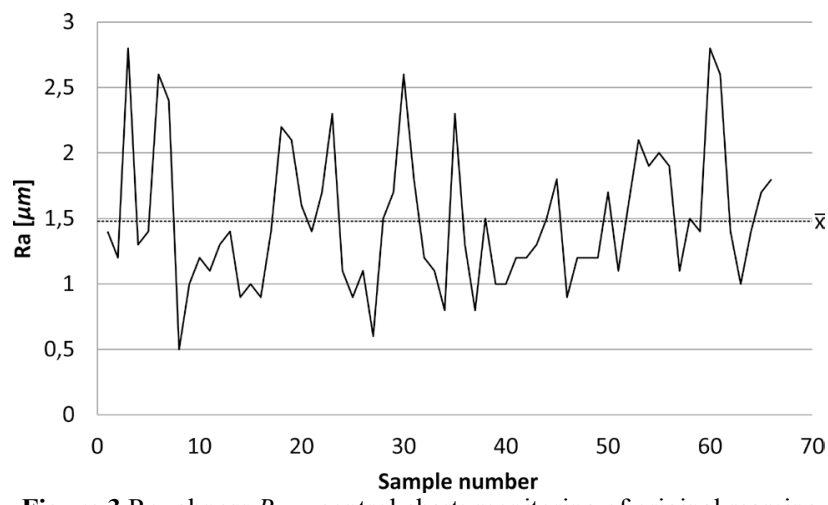

Figure 3 Roughness $R a$ x-control chart; monitoring of original reaming process

First monitoring of the original reaming process was performed with measuring random samples from regular production. SPC x-control charts are given in Fig. 2 and Fig. 3, and show poor capability of the process. Specifications of original reaming process were for cylindricity $/ 0 / \leq 12 \mu \mathrm{m}$ and for roughness $R a \leq 1,6 \mu \mathrm{m}$. In order to improve poor process capability quality actions for machining technology must be taken. In order to reach those improvements systematic problem solving approach is needed

\subsection{Pre-experiments}

Fig. 2 and Fig. 3 show results of monitoring process for the initial cylinder bore manufacturing process. Measurements included a half-year period. Sample from each batch is accounted for 6 consecutive products manufactured within the same series. Process capability index for cylindricity $C_{\mathrm{pk}(C y l)}=0,18$ and surface roughness $C_{\mathrm{pk}(R a)}=0,07$ represents very poor manufacturing process control. The large dispersion of the measurements within the same series and uniqueness of results from batch to batch shows low measurement reproducibility.

Honing gives best results when reaming process specifications are reached and if there is small deviation in cylindricity between consecutive work pieces. Even if mentioned requirements are not respected all derogations could be compensated during honing process. In this case additional setting of honing parameters for each work peace individually is needed. This way honing process becomes production bottle neck and manufacturing costs are increased.

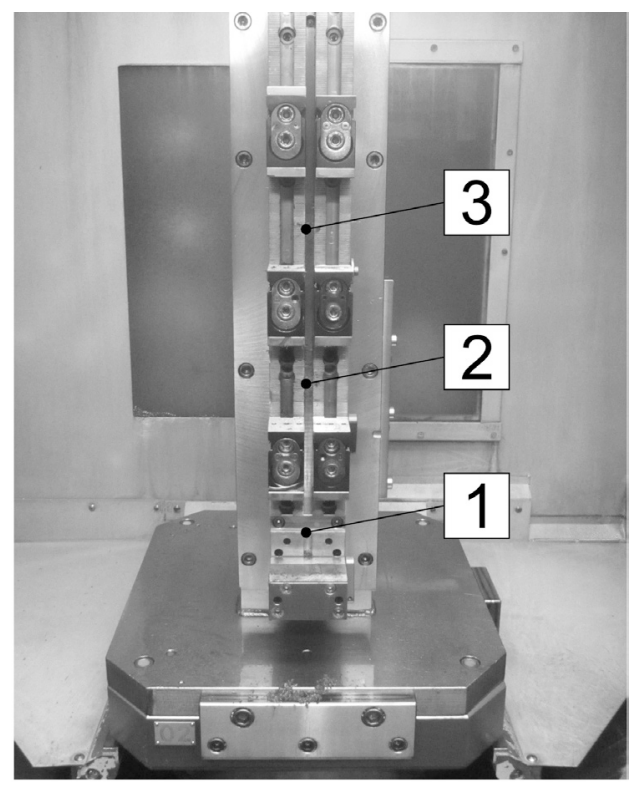

Figure 4 Clamping device with three nests

The existing clamping device allows mounting of three pieces, as shown in Fig. 4. According to the findings monitoring of the process within one batch was performed. Cylindricity /o/ control chart in Fig. 5 demonstrates the shortcoming of the clamping device. Shortcomings are evident as trend deviations of measurements of three consecutive samples. The results show that only $1^{\text {st }}$ nest ensures an adequate rigidity, allows the desired results and ensure reproducibility of the measurement (nest No. 1 in Fig. 4). Nests No. 2 and 3, due to poor rigidity, do not allow adequate reproducibility.

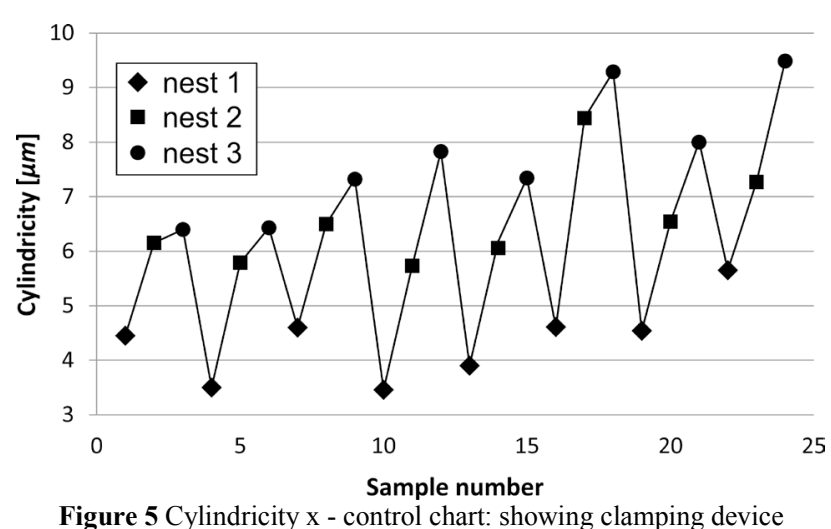

Figure 5 Cylindricity $\mathrm{x}$ - control chart: showing clamping device weaknes 
Region of operability for reaming was determined with pre-experiments using regular procedure [18]. Reamer with in-operation time (tool life) $t=250 \mathrm{~min}$ was utilised. Experiments were started from the existing production parameters settings (bold point in Fig. 6; spindle speed $S$ $=350 \mathrm{rev} / \mathrm{min}$, feed rate $f=100 \mathrm{~mm} / \mathrm{min}$ ) and carried out in a diagonal direction of the $S / f$ diagram.

Extreme values of technological window (rectangle in Fig. 6) were determined with a point where machining conditions were still acceptable. The criterion for determining the technological window was set on; cylindricity $/ \circ / \leq 4 \mu \mathrm{m}$ and surface roughness $R a \leq 1,1$ $\mu \mathrm{m}$. Goal of using such criteria was determination of more robust region of operability that would allow experiments conducting in regular production, without additional honing parameters setting. Resulted technological window limits shown in Fig. 6 are listed in
Tab. 1, as first (-1) and second (1) level of the reaming parameters.

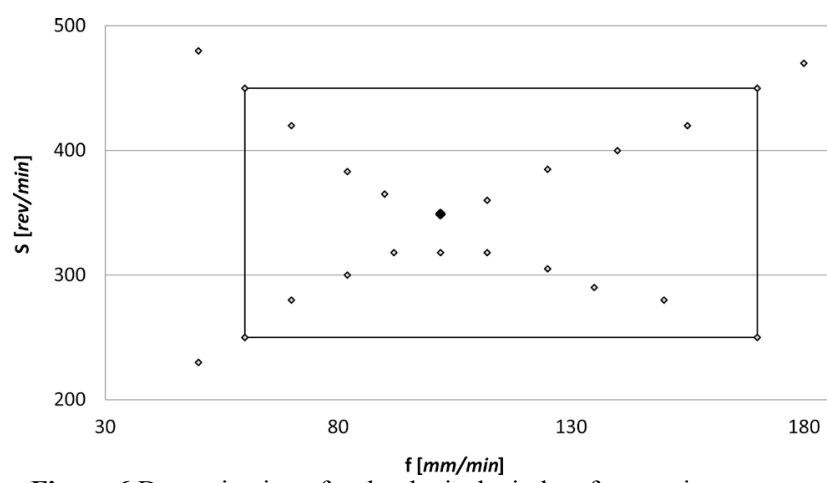

Figure 6 Determination of technological window for reaming process

Table $1 \mathrm{DOE}$ and experimental results

\begin{tabular}{|c|c|c|c|c|c|c|c|c|c|c|}
\hline \multirow{2}{*}{$\begin{array}{l}\text { Exp. } \\
\text { No. }\end{array}$} & \multirow{2}{*}{\multicolumn{2}{|c|}{ Coded level }} & \multicolumn{2}{|c|}{ Actual setting values } & \multirow{2}{*}{$\begin{array}{c}\text { Cylindricity } \\
(\mu \mathrm{m})\end{array}$} & \multicolumn{4}{|c|}{ Roughness $R a(\mu \mathrm{m})$} & \multirow{2}{*}{$\begin{array}{c}\text { Average } R a \\
(\mu \mathrm{m})\end{array}$} \\
\hline & & & $f(\mathrm{~mm} / \mathrm{min})$ & $S(\mathrm{rev} / \mathrm{min})$ & & $R a_{1}$ & $R a_{2}$ & $R a_{3}$ & $R a_{4}$ & \\
\hline 1 & -1 & -1 & 60 & 250 & 1,99 & 0,1 & 0,2 & 0,2 & 0,1 & 0,15 \\
\hline 2 & -1 & -1 & 60 & 250 & 2,34 & 0,2 & 0,2 & 0,4 & 0,3 & 0,275 \\
\hline 3 & -1 & -1 & 60 & 250 & 2,24 & 0,1 & 0,1 & 0,2 & 0,3 & 0,175 \\
\hline 4 & $\begin{array}{ll}1 \\
-1\end{array}$ & 1 & 60 & 450 & 2,83 & 0,2 & 0,2 & 0,3 & 0,2 & 0,225 \\
\hline 5 & -1 & 1 & 60 & 450 & 2,36 & 0,3 & 0,2 & 0,2 & 0,2 & 0,225 \\
\hline 6 & -1 & 1 & 60 & 450 & 2,95 & 0,1 & 0,2 & 0,1 & 0,2 & 0,15 \\
\hline 7 & 1 & -1 & 170 & 250 & 3,38 & 1,1 & 1,1 & 1,3 & 1,1 & 1,15 \\
\hline 8 & 1 & -1 & 170 & 250 & 3,21 & 0.8 & 0,9 & 1,2 & 1 & 0,975 \\
\hline 9 & 1 & -1 & 170 & 250 & 3,09 & 1 & 1 & 1,1 & 1,2 & 1,075 \\
\hline 10 & 1 & 1 & 170 & 450 & 3,34 & 1,3 & 1,2 & 1,2 & 1,3 & 1,25 \\
\hline 11 & 1 & 1 & 170 & 450 & 4,18 & 1 & 0,7 & 1,7 & 1,4 & 1,2 \\
\hline 12 & 1 & 1 & 170 & 450 & 2,99 & 0,9 & 0,8 & 1 & 1,2 & 0,975 \\
\hline
\end{tabular}

\subsection{Experimental setup}

The experimental part was carried out in regular production and thus includes real production noise factors, which are in laboratory testing difficult to simulate. Control factors and their levels were chosen on a base of pre-experiments and review of the reaming

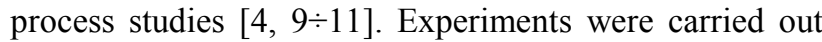
using $L_{12}$ orthogonal array and analysed with ANOVA.

In the experimental work the effects of reamer's tool life, cutting parameters and the part position in the clamping device on the cylindricity and surface roughness of the cylinder bore have been studied. Experiments were carried out at ambient temperature $T=23{ }^{\circ} \mathrm{C}$ with standard reamer DIN 8094B with diameter of $11,75 \mathrm{~mm}$. Control factors - parameters and their values (see Tab. 1) were determined by pre-experiments and constitute an adequate range of parameters, which allow achieving the required specifications.

Experiments were carried out on the MoriSeikiNH5000 machine tool equipped with the option of tool life monitoring and it allows measurements of tool in-operation time in minutes. The workpiece material was C45E steel with dimensions of $70 \times 100 \times 100 \mathrm{~mm}$. The maximum reamers tool life, which was determined by the experience of the preceding series, is $180 \mathrm{~min}$. In the present experimental work reamer with a $40 \%$ greater operation time was used. Reamer tool operation time was $t=250 \mathrm{~min}$. The goal of using such tool was to demonstrate that it is possible to achieve the required specifications with longer tool life and thus create additional savings.

\subsection{Bore cylindricity and roughness measurements}

Cylinder bore cylindricity measurements were carried out using Tayloround 585 device.

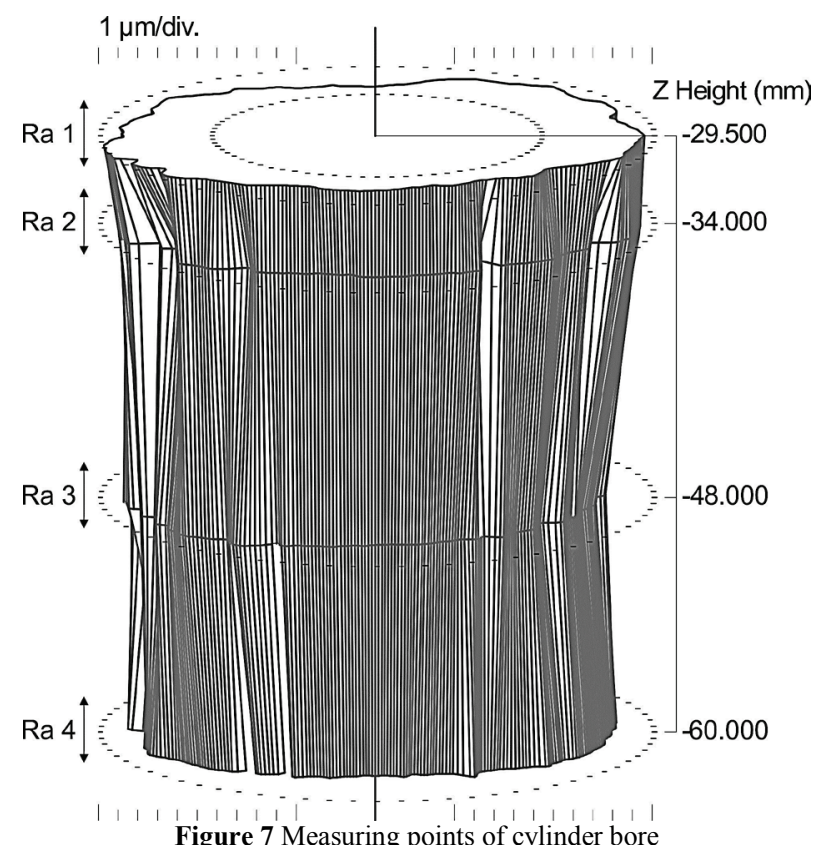

Figure 7 Measuring points of cylinder bore 
For each specimen four roundnesses that together define cylindricity as suggested by De Chiffre et al. [4], Goeldel et al. [5], Stepien [6], Wen et al. [7] at different bore positions, were recorded (Fig. 7).

To characterize surface roughness, surface topology parameter $R a$ as suggested by Brito et al. [8] and Raykar et al. [19], was used. Measurements were carried out using roughness tester MarSurf GD25. For each specimen four profiles at four different cylinder bore positions were recorded. Results for individual experiment are given in Tab. 1.

\section{Results and discussion}

Bore cylindricity and average surface roughness $R a$ resulting during machining of cylinder bore were measured after the experiments. The experimental results are given in Tab. 1. The correlation between the control factors and results of cylinder bore machining were obtained with multiple regressions. A multiple analysis of variance (ANOVA) was used for identifying the factors significantly affecting the preference measures, cylindricity and surface roughness, after machining. The experimental results and optimization procedure were analysed with Design Expert software [20].

\subsection{Regression model for cylindricity}

The results of cylindricity formed in reaming cylinder bore are evaluated in Tab. 2. For determination of the optimal set of parameters 'cylindricity' linear regression graphs were used (Fig. 8).

Table 2 ANOVA for cylindricity factorial mode

\begin{tabular}{|c|c|c|c|c|c|}
\hline 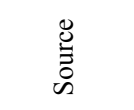 & 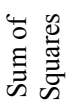 & 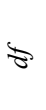 & 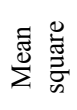 & 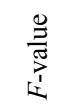 & 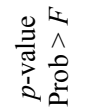 \\
\hline Model & 2,98 & 2 & 1,49 & 12,25 & 0,0027 \\
\hline $\mathrm{A}-f$ & 2,50 & 1 & 2,50 & 20,56 & 0,0014 \\
\hline B - S & 0,48 & 1 & 0,48 & 3,94 & 0,0783 \\
\hline$R$-Squared & \multicolumn{5}{|c|}{0,7313} \\
\hline$S / N$ & \multicolumn{5}{|c|}{7,528} \\
\hline
\end{tabular}

Both control factors namely spindle speed $S$ and feed rate $f$ were recognized as significant (Tab. 2) and give the best result at lower level setting ( -1 level). Regression model for cylindricity is defined with regression Eq. (1):

Cylindricity $=1,2535+8,30 \cdot 10^{3} \cdot f+2 \cdot 10^{3} \cdot S$

Cylindricity regression model shows that cylindricity increases with the increase of feed rate $f$ and spindle speed $S$. The feed rate has the most dominant effect on machining cylinder bore cylindricity, while spindle speed influence is much lower.

The Model $F$-value of 12,25 implies the model is significant. There is only a $0,27 \%$ chance that a 'Model $F$-Value' this large could occur due to noise. The signal to noise ratio $(S / N)$ greater than 4 is desirable. Cylindricity model $S / N$ ratio of 7,528 indicates an adequate signal. This model can be used to navigate the design space for cylindricity.

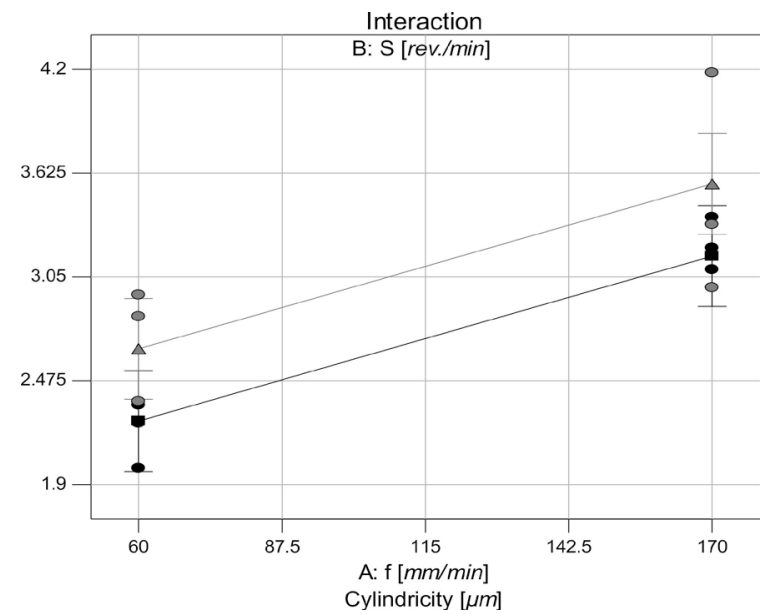

Figure 8 Cylindricity interaction graph for feed rate (A) and spindle speed (B)

\subsection{Regression model for surface roughness}

The quality of machined surface generated in reaming cylinder bore is evaluated in terms of average surface roughness $(R a)$ values. The graph in Fig. 9 and ANOVA in Tab. 3 were used to determine the optimal set of parameters. From the linear regression graph and ANOVA, the control factor - spindle feed $f$ is recognized as significant and gives the best result at -1 level. On the other hand control factor - spindle speed $S$ was recognized as not significant.

Table 3 ANOVA for roughness factorial model

\begin{tabular}{|c|c|c|c|c|c|}
\hline 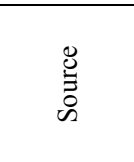 & 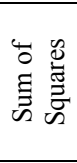 & $\nabla$ & 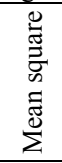 & 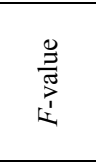 & 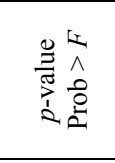 \\
\hline Model & 2,45 & 1 & 2,45 & 309,39 & $<0,0001$ \\
\hline $\mathrm{A}-f$ & 2,45 & 1 & 2,45 & 309,39 & $<0,0001$ \\
\hline$R$-Squared & \multicolumn{5}{|c|}{0,9687} \\
\hline$S / N$ & \multicolumn{5}{|c|}{24,875} \\
\hline
\end{tabular}

Regression model for surface roughness $R a$ is defined with the following Eq. (2):

$R a_{\text {average }}=-0,29318+8,21970 \cdot 10^{-3} \cdot f$

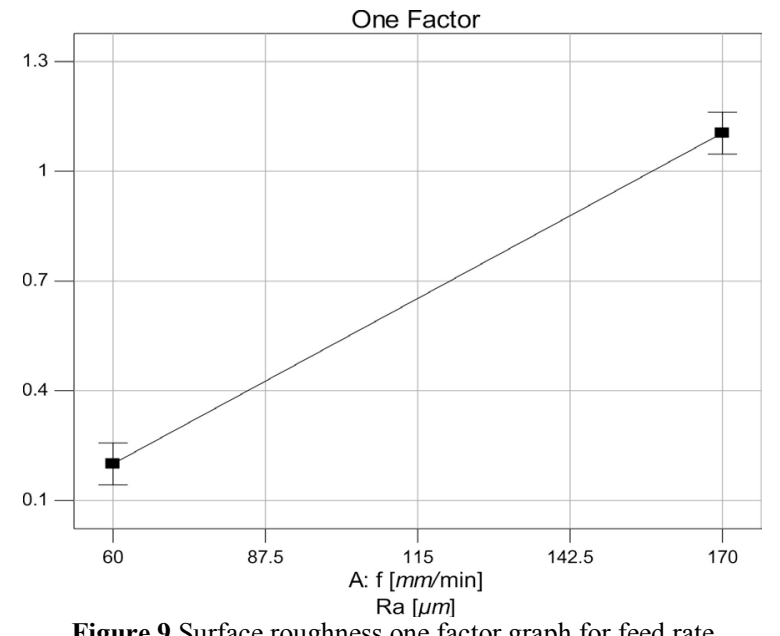

Figure 9 Surface roughness one factor graph for feed rate

Feed rate has main role in achieving surface roughness. The model $F$-value of 309,39 implies the 
model is significant. There is only a $0,01 \%$ chance that value this large could occur to noise.

\subsection{Optimization with conformation test for target cylindricity and surface roughness}

For the reaming process optimization both regression models for bore cylindricity and surface roughness were used. Even specifications prescribe cylindricity $/ 0 /<3$ $\mu \mathrm{m}$, in order to get more robust reaming process, target value for bore cylindricity was set at $/ \mathrm{o} /=2 \mu \mathrm{m}$ (first criteria). Cylindricity $/ \circ /_{\text {low }}=1,5 \mu \mathrm{m}$ represents lower limit and cylindricity $/ \circ /$ up $=0,3 \mu \mathrm{m}$ upper limit in the optimization procedure (Tab. 4). Target value for surface roughness $R a$ (second criteria) was set at $R a=0,3 \mu \mathrm{m}$ where $R a_{\text {low }}=0,15 \mu \mathrm{m}$ is the lower and $R a_{\text {up }}=0,4 \mu \mathrm{m}$ is the upper limit in the optimization procedure (Tab. 4).

Review of the studies on reaming process $[4,10]$ and preceding experiences reveal that from machining point of view bore cylindricity specification is more difficult to meet than surface roughness specifications. From this reason the greatest weight was set on cylindricity target.

Table 4 Responses criteria for optimization

\begin{tabular}{|c|c|c|c|c|c|}
\hline & Target $(\mu \mathrm{m})$ & $\begin{array}{l}\text { Lower limit } \\
\qquad(\mu \mathrm{m})\end{array}$ & $\begin{array}{l}\frac{\overrightarrow{0}}{00} \\
\frac{00}{3}\end{array}$ & $\begin{array}{l}\text { Upper limit } \\
\qquad(\mu \mathrm{m})\end{array}$ & $\begin{array}{l}\frac{7}{00} \\
\frac{.00}{3}\end{array}$ \\
\hline Cylindricity & 2 & 1,5 & 5 & 3 & 1 \\
\hline$R a$ & 0,3 & 0,15 & 3 & 0,4 & 1 \\
\hline
\end{tabular}

Regression models optimisation with above target criteria settings resulted in a solution for control factors i.e. process parameters settings shown in Tab. 5 .

Table 5 Control factors and predicted responses values

\begin{tabular}{|c|c|c|c|c|}
\hline $\begin{array}{c}f \\
(\mathrm{~mm} / \mathrm{min})\end{array}$ & $\begin{array}{c}S \\
(\text { rev./min })\end{array}$ & $\begin{array}{c}\text { Cylindricity } \\
(\mu \mathrm{m})\end{array}$ & $\begin{array}{c}R a \\
(\mu \mathrm{m})\end{array}$ & Desirability \\
\hline 72,2 & 250 & 2,35 & 0,3 & 0,805 \\
\hline
\end{tabular}

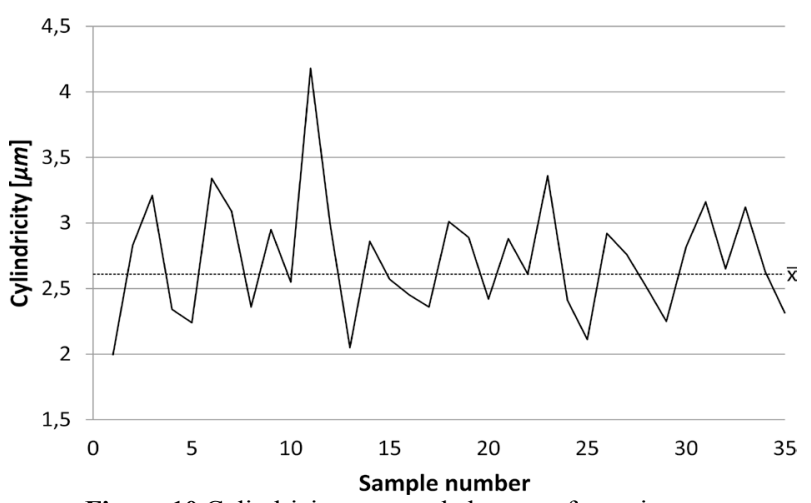

Figure 10 Cylindricity x-control chart: conformation test

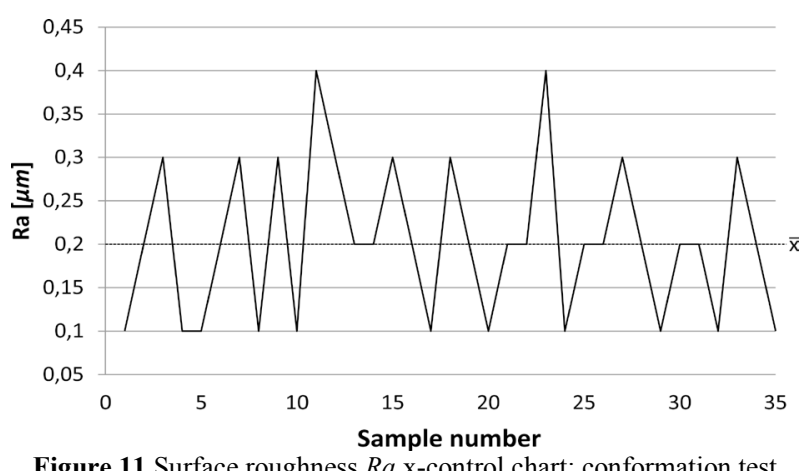

Desirability of 0,805 in Tab. 5 shows great fit between responses criteria set and predicted responses values, where Desirability of 1 gives perfect fit.

In order to use optimization results in real small batch production, robustness of the optimization model needs to be confirmed in practice as well. Optimised control factors values were implemented in production and 35 successive samples were measured. Results are presented in x-control charts for both cylindricity and $R a$ in Fig. 10 and Fig. 11.

Average values for cylindricity $/ 0 /$ ave $=2,677 \mu \mathrm{m}$ and roughness $R a_{\text {ave }}=0,203 \mu \mathrm{m}$ are in reasonable agreement with predicted responses values. Interpretation of such results could lead to honing process elimination, but dispersion of individual measurements is rather high.

Tab. 6 shows reaming process capabilities improvements. Process capability index $C_{p k}$ that was calculated for original and improved reaming process respectively is shown in Tab. 6. USL represents Upper Specification Limit and $\sigma$ standard deviation of the measurements.

Table 6 Reaming process improvements

\begin{tabular}{|l|c|c|c|}
\hline \multirow{2}{*}{} & \multicolumn{3}{|c|}{ Cylindricity $(\mu \mathrm{m})$} \\
\cline { 2 - 4 } & $U S L$ & $\sigma$ & $C_{\mathrm{pk}}$ \\
\hline Reaming original & 12 & 4 & 0,18 \\
\hline Reaming optimised & 12 & 0,45 & 6,94 \\
\hline Reaming optimised; Honing specifications & 3 & 0,45 & 0,21 \\
\hline Reaming optimised; Loose tolerances & 4 & 0,45 & 0,96 \\
\hline & \multicolumn{3}{|c|}{$R a(\mu \mathrm{m})$} \\
\cline { 2 - 4 } & $U S L$ & $\sigma$ & $C_{\mathrm{pk}}$ \\
\hline Reaming original & 1,6 & 0,54 & 0,07 \\
\hline Reaming optimised & 1,6 & 0,09 & 5,23 \\
\hline Reaming optimised; Honing specifications & 0,4 & 0,09 & 0,74 \\
\hline Reaming optimised; Loose tolerances & 0,5 & 0,09 & 1,11 \\
\hline
\end{tabular}

It can be seen that reaming process capability improvement is enormous. Even when honing specifications are used for improved reaming process its capability index is higher than in original state. Optimisation of reaming process results in drastic honing time reduction. Hydraulic valves housings (cylinders) with more loose tolerances $(/ \circ / \leq 4 \mu \mathrm{m}$ and $R a \leq 0,5 \mu \mathrm{m})$ could be manufactured without honing.

\section{Conclusions}

Reaming process for cylinder manufacturing was improved using SPC and DOE methodology. The following conclusions can be made:

- SPC results indicate that original reaming process does not meet specifications. All reaming process derogations were at original manufacturing process compensated with additional honing parameters settings for each work piece individually.

- Clamping device lack of rigidity was minimized with focusing on only one (of three) nest.

- Reaming process region of operability was determined with pre-experiments using regular procedure. Criterion of determining was set in the way that would allow experiments conducting in regular production, without additional honing parameters setting.

- Regression analysis gives models for both responses under consideration, namely cylinder cylindricity and 
surface roughness, and they are adequate at $73 \%$ and $96 \%$ confidence level respectively.

- Results show that feed rate influences both responses while also small effect of spindle speed on cylindricity was recognised.

- Two criteria for reaming process optimisation were applied; cylindricity $/ \circ / \leq 2 \mu \mathrm{m}$ and $R a \leq 0,3 \mu \mathrm{m}$. Conformation test in real production environment confirms regression models and the optimisation strategy.

With reaming process optimisation capability of the process improved enormously and results in drastic honing time reduction. Cylinders with more loose tolerances $(/ \circ / \leq 4 \mu \mathrm{m}$ and $R a \leq 0,5 \mu \mathrm{m})$ could be manufactured without honing.

- In experiments reamer with $40 \%$ longer in-operation time as in original production was used.

- In order to reach original specification with resulting multi-criteria optimization model (with reaming only): first upgrade of original clamping device is needed and second new in-operation tool life limit must be defined.

\section{References}

[1] Zou, J.; Zhang, Y. Z.; Miao, C. X. The single machine serial batch production scheduling with outsourcing allowed. // Tehnicki Vjesnik-Technical Gazette. 22, 2(2015), pp 297302, DOI: 10.17559/TV-20150312154507

[2] Majdic, F.; Pezdirnik, J.; Kalin, M. Experimental validation of the lifetime performance of a proportional $4 / 3$ hydraulic valve operating in water. // Tribology International. 44, (2011), pp. 2013-2021. DOI: 10.1016/j.triboint.2011.08.020

[3] Montgomery, D. C. Design and Analysis of Experiments, Sixth Ed. Arizona state university, John Wiley, USA, 2005.

[4] De Chiffre, L.; Tesello, G.; Piska, M.; Müller, P. Investigation on capability of the reaming process using minimal quantity lubrication. // CIRP Journal of Manufacturing Science and Technology. 2, (2009), pp. 4754. DOI: 10.1016/j.cirpj.2009.08.004

[5] Goeldel, B.; Voisin, J.; Dumur, D.; Mansori, M. E.; Frabolot, M. Flexible right sized honing technology for fast engine finishing. // CIRP Annals - Manufacturing Technology. 62, (2013), pp. 327-330. DOI: 10.1016/j.cirp.2013.03.075

[6] Stepien, K. In situ measurement of cylindricity - problems and solutions. // Precision Engineering. 38, (2014), pp. $697-$ 701. DOI: 10.1016/j.precisioneng.2014.02.007

[7] Wen, X.; Zhao, Y.; Wang, D.; Pan, J. Advanced Monte Carlo and GUM methods for the evaluation of measurement uncertainty of cylindricity error. // Precision Engineering. 37, (2013), pp. 856-864. DOI: 10.1016/j.precisioneng.2013.05.002

[8] Brito, T. G.; Paiva, A. P.; Ferreira, J. R.; Gomes, J. H. F.; Balestrassi, P. P. A normal boundary intersection approach to multiresponse robust optimization of the surface roughness in end milling process with combined arrays. // Precision Engineering. 38, (2014), pp. 628-638. DOl: 10.1016/j.precisioneng.2014.02.013

[9] Korkut, I.; Kucuk, Y. Experimental analysis of the deviation from circularity of bored hole based on the Taguchi method. // Journal of Mechanical Engineering. 5, (2010), pp. 340-346.

[10] Müller, P.; Genta, G.; Barbato, G.; De Chiffre, L.; Levi, R. Reaming process improvement and control: An application of statistical engineering. // CIRP Journal of Manufacturing Science and Technology. 5, (2012), pp. 196-201. DOI: 10.1016/j.cirpj.2012.07.005
[11] Xiao, W.; Zi, Y.; Chen, B.; Li, B.; He, Z. A novel approach to machining condition monitoring of deep hole boring. // Internal Journal of Machine Tools \& Manufacture. 77, (2014), pp. 27-33. DOI: 10.1016/j.jimachtools.2013.10.009

[12] Burlikowska, M. D. Quality estimation of process with usage control charts type X-R and quality capability of process $C_{\mathrm{p}}$, $C_{\mathrm{pk}}$. // Journal of Materials Processing Technology. 162-163, (2005), pp. 736-743. DOI: 10.1016/j.jmatprotec.2005.02.210

[13] Hassan, A.; Basksh, M. S. N. Feature selection for SPC chart pattern recognition using fractional factorial experimental design. // Intelligent Production machines and Systems, (2006).

[14] Jose, V.; Nebot, A.; Liu, J.; Subiron, F. R. Quality prediction and compensation in multi-station machining processes using sensor-based fixtures. // Robotics and Computer Integrated Manufacturing. 28, (2014), pp. 208-219.

[15] Goldarag, F. E.; Barzegar, S.; Babaei, A. An Experimental Method for Measuring the Clamping Force in Double Lap Simple Bolted and Hybrid (Bolted-Bonded) Joints. // Transactions of FAMENA. 39, 3(2015), pp. 87-94

[16] Todorovic, P. M.; Buchmeister, B.; Djapan, M. J.; Vukelic, D.; Milosevic, M. D.; Tadic, B.; Radenkovic, M. M. Comparative model analysis of two types of clamping elements in dynamic conditions. // Tehnicki VjesnikTechnical Gazette. 21, 6(2014), pp. 1273-1279

[17] Montgomery, D. C. Using statistically designed experiments for process development and improvement: an application in electronics manufacturing. // Robotics and Computer Integrated Manufacturing. 16, (2000), pp. 55-63. DOI: 10.1016/S0736-5845(99)00057-5

[18] Anfor Standard NFE 66-520. Couple outil-matiere: Domaine de fonctionnement des outils coupants, Vol. 1-6, 1994.

[19] Raykar, S. J.; D’Addona, D. M.; Kramar, D. Analysis of surface topology in dry machining of EN-8 steel. // Procedia Materials Science. 6, (2014), 931-938. DOI: 10.1016/j.mspro.2014.07.163

[20] Stat-Ease Corporation. Design-expert software user manual. Version 9, Minneapolis 2014.

\section{Authors' addresses}

\section{Dr. Peter Eniko, Quality manager}

Difa d.o.o.

Kidričeva cesta 91, 4220 Škofja Loka, Slovenia

E-mail: peter.eniko@difa.si

\section{Davorin Kramar, PhD, Assistant Professor}

Faculty of Mechanical Engineering, University of Ljubljana, Askarceva 6, 1000 Ljubljana, Slovenia

E-mail: davorin.kramar@fs.uni-lj.si 